\title{
ANALISIS DAMPAK PEMBANGUNAN PELABUHAN PATIMBAN DI KECAMATAN PUSAKANEGARA TERHADAP KONDISI SOSIAL EKONOMI MASYARAKAT SEKITAR
}

\author{
Asep Bambang Iryana ${ }^{1}$ \\ 1) Jurusan Ilmu Pemerintahan STIP-AN \\ email koresepondensi: bepe.a20@gmail.com
}

\begin{abstract}
Abstrak
Pelabuhan Patimban yang berlokasi di Desa Patimban, Kecamatan Pusakanegara, Kabupaten Subang, Provinsi Jawa Barat, ditetapkan sebagai proyek strategis nasional sebagaimana diatur dalam Peraturan Presiden Nomor 3 Tahun 2016 tentang Percepatan Pelaksanaan Proyek Strategis Nasional. Penyelenggaraan Pelabuhan Patimban sebagai proyek strategis nasional itu, menurut Perpres ini, meliputi kegiatan perencanaan, pembangunan, pengoperasian dan pengusahaan, pembinaan teknis dan pembinaan manajemen pengoperasian pelabuhan, serta pembinaan untuk menjamin keselamatan pelayaran dan lingkungan. Pembangunan pelabuhan ini merupakan strategi Pemerintah untuk mengurangi kelebihan kapasitas di Pelabuhan Tanjung Priok. Pada dasarnya pelabuhan mempunyai peran penting dalam perkembangan industri, perdagangan dan jasa serta harapan Kabupaten Subang menjadi kota industri metropolitan.
\end{abstract}

Teknik pengumpulan data yaitu : observasi, wawancara dan dokumentasi. Teknik keabsahan data yang digunakan dalam penelitian yaitu triangulasi sumber dan triangulasi metode. Teknik analisis data yang digunakan yaitu teknik analisis data kualitatif yaitu pengumpulan data, reduksi data, penyajian data dan penarikan kesimpulan.

Berdasarkan hasil pembahasan yang didapat tentang Analisis Dampak Pembangunan Pelabuhan Patimban di Kecamatan Pusakanegara Terhadap Kondisi Sosial Ekonomi Masyarakat Sekitar bahwa terdapat tiga poin yaitu : dampak kondisi sosial ekonomi, dampak mata pencaharian dan dampak mobilitas penduduk. Dampak sosial ekonomi terjadinya persepsi masyarakat terhadap perubahan yang positif dan negatif. Perubahan yang positif yaitu lokasi Desa Patimban yang menjadi lebih terkenal dibanding sebelum adanya pemabngunan pelabuhan. Perubahan negatif yaitu dengan adanya pemangunan Pelabuhan Patimban dimana nantinya akan terjadi interaksi sosial dimana akan ada banyak penduduk yang datang dari luar wilayah baik yang datang sebagai pencari kerja karena nantinya akan ada banyak perusahaan yang beroperasional di Pelabuhan Patimban. Tentu hal ini lambat laun akan merubah kebiasaan masyarakat sekitar seiring dengan perkembangan Pelabuhan Patimban. Dampak mata pencaharian akan tergesernya mata pencaharian yang tadinya sebagai Petani dan Nelayan, dimana Petani akan berkurang lahan pertaniannya sebagai dampak pembebasan lahan yang diperuntukan untuk kepentingan pelabuhan serta Nelayan yang semakin jauh jarak melautnya. Dampak mobilitas penduduk yang disebabkan oleh adanya pembangunan Pelabuhan Patimban meliputi tiga pola yaitu diatur pemerintah, keinginan sendiri dan tergantung orang lain.

Kata Kunci : Pelabuhan, Dampak, Industri, Mobilitas 


\begin{abstract}
Patimban Port, which is located in Patimban Village, Pusakegara District, Subang Regency, West Java Province, is designated as a national strategic project as regulated in Presidential Regulation No.3 of 2016 concerning the Acceleration of Implementation of National Strategic Projects. The implementation of Patimban Port as a national strategic project, according to this Presidential Decree, includes planning, development, operation and exploitation activities, technical guidance and development of port operation management, as well as guidance to ensure shipping safety and the environment. This port development is the Government's strategy to reduce excess capacity at Tanjung Priok Port. Basically, ports have an important role in the development of industry, trade and services and hope that Subang Regency will become a metropolitan industrial city.
\end{abstract}

Data collection techniques, namely: observation, interviews and documentation. The data validity techniques used in the study were source triangulation and method triangulation. The data analysis technique used is qualitative data analysis techniques, namely data collection, data reduction, data presentation and conclusion.

Based on the results of the discussion obtained about the Analysis of the Impact of the Development of Patimban Port in Pusakegara District on the SocioEconomic Conditions of the Surrounding Community, there are three points, namely: the impact of socio-economic conditions, the impact of livelihoods and the impact of population mobility. The socio-economic impact of the occurrence of public perceptions of positive and negative changes. A positive change is the location of Patimban Village, which has become more famous than before the port development. A negative change is the development of the Patimban Port where there will be social interaction where there will be many residents who come from outside the region who come as job seekers because later there will be many companies operating in the Patimban Port. Of course this will gradually change the habits of the surrounding community along with the development of Patimban Port. The impact of livelihoods will be the displacement of their former livelihoods as farmers and fishermen, where farmers will have less agricultural land as a result of land acquisition for the benefit of ports and fishermen who are increasingly distant to sea. The impact of population mobility caused by the development of Patimban Port includes three patterns, namely being regulated by the government, their own will and depending on others.

Keywords: Port, Impact, Industry, Mobility 


\section{PENDAHULUAN}

Pembangunan prasarana infrastruktur di Indonesia telah berlangsung cukup lama dan investasi yang dikeluarkan sudah sangat besar. Namun masih banyak masalah yang dialami negara kita khususnya mengenai perencanaan yang lemah, kuantitas yang belum mencukupi, dan kualitas yang rendah. Terkait dengan perancanaan yang dilakukan oleh Pemerintah Pusat maupun Pemerintah Daerah tidak selalu berjalan dengan baik selalu saja timbul masalah disetiap perencanaan yang dilakukan oleh pemerintah tentu hal ini akan berdampak nantinya pada hasil karena sebaik-baiknya perencanaan adalah sebaik-baiknya hasil, tetapi seburuk-buruknya perencanaan adalah seburuk-buruknya hasil. Anggaran infrastruktur setiap tahun mengalami peningkatan, akan tetapi penelitian dari laporan World Economic Forum menunjukkan peringkat kualitas infrastruktur di Indonesia masih tergolong rendah. Pentingnya pembangunan fasilitas sarana dan prasarana infrastruktur ini seperti yang dinyatakan oleh De dan Ghosh (2005:81) bahwa kendala yang dihadapi daerah-daerah maupun negaranegara lebih kepada persoalan ekonomi yaitu bagaimana memastikan baiknya infrastruktur supaya lebih bermanfaat.

Pelabuhan Patimban yang berlokasi di Desa Patimban, Kecamatan Pusakanegara, Kabupaten Subang, Provinsi Jawa Barat, ditetapkan sebagai proyek strategis nasional, sebagaimana diatur dalam Peraturan Presiden Nomor 3 Tahun 2016 tentang Percepatan Pelaksanaan Proyek Strategis Nasional," bunyi pasal 1 perpres tersebut, seperti dikutip laman resmi Sekretariat Kabinet, Senin, 13 Juni 2016. Penyelenggaraan Pelabuhan Patimban sebagai proyek strategis nasional itu, menurut Perpres ini, meliputi kegiatan perencanaan, pembangunan, pengoperasian dan pengusahaan, pembinaan teknis dan pembinaan manajemen pengoperasian pelabuhan, serta pembinaan untuk menjamin keselamatan pelayaran dan lingkungan. Dalam Perpres ini dikatakan penyelenggaraan Pelabuhan Patimban yang terdiri atas perencanaan, pembangunan, pengoperasian dan pengusahaan, serta pembinaan digelar Kementerian Perhubungan. Untuk kegiatan pembangunan dan pengoperasian, Kementerian dapat bekerja 
sama dengan badan usaha pelabuhan. Penetapan itu tertuang dalam Peraturan Presiden Nomor 47 Tahun 2016 tentang Penetapan Pelabuhan Patimban di Kabupaten Subang, Provinsi Jawa Barat, sebagai Proyek Strategis Nasional. Pembangunan pelabuhan ini merupakan strategi Pemerintah untuk mengurangi kelebihan kapasitas di Pelabuhan Tanjung Priok. Pembangunan Pelabuhan Patimban ini diharapkan juga dapat sebagai stimulator pengembangan wilayah di daerah Subang.

Pada dasarnya pelabuhan mempunyai peran penting dalam perkembangan industri, perdagangan dan jasa serta harapan Kabupaten Subang menjadi kota industri metropolitan. Hal ini disebabkan karena pelabuhan merupakan salah satu prasarana transportasi yang cukup vital bagi sebuah negara, terutama pada negara maritim seperti Indonesia. Pelabuhan juga merupakan salah satu usaha yang dapat memberikan kontribusi bagi perekonomian baik nasional maupun daerah, karena dengan adanya pelabuhan maka kegiatan ekonomi suatu negara atau daerah akan dapat menjadi lebih lancar. Menurut Triatmodjo dalam Zulkifli (2017), berdasarkan pada fakta yang ada pada beberapa negara, barangbarang ekspor impor sebagian besar dikirim melalui jalur laut membutuhkan pelabuhan atau tempat untuk bertambat, meskipun rute perjalanan yang dituju dapat dilalui oleh alat transportasi lain. Hal tersebut dapat terjadi mengingat jumlah barang yang dapat diangkut oleh kapal lebih banyak dibandingkan dengan jumlah barang yang dapat diangkut oleh armada lain.

Aktivitas pelabuhan di Indonesia selama ini masih didominasi di Pelabuhan Tanjung Priuk, sehingga membuat lalu lintas di Pelabuhan Tanjung Priuk sering mengalami kepadatan dan arus lalu lintas kendaraan khususnya ruas antara Bekasi-Tanjung Priok, Jakarta selalu mengalami kemacetan sehingga membuat biaya logistik perusahaan yang menggunakan jasa pelabuhan Tanjung Priuk menjadi tinggi. Dengan alasan itu pemerintah membangunan Pelabuhan Patimban yang berlokasi di Kabupaten Subang. Tujuan pembangunan Pelabuhan Patimban yakni mengurangi biaya logistik, memperkuat ketahanan ekonomi, mengurangi 
tingkat kepadatan lalu lintas di Jakarta, serta menjamin keselamatan pelayaran termasuk area eksplorasi minyak dan gas. Kita ketahui bersama bahwa kepadatan Pelabuhan Tnjung Priuk Jakarta membawa dampak tersendatnya perekonimian dan roda transportasi dengan kemacetan di area sekitar Tanjung Priuk dan sekitarnya dengan alasan itulah Pemerintah Pusat membangun Pelabuhan baru di Patimban tepatnya di Kabupaten Subang untuk memberikan kelancaran perekomian Negara dan Daerah dalam hal ini adalah Kabupaten Subang. Pembangunan Pelabuhan Patimban ditargetkan selesai pada tahun 2020. Adapun rencana pembangunan Pelabuhan Patimban meliputi pembangunan Car Terminal Pelabuhan Patimban direncanakan memiliki kapasitas tampung 250.000 sampai 300.000 kendaraan per tahun. Pelabuhan Patimban juga direncanakan akan melayani jenis muatan Peti Kemas dan Kendaraan Bermotor yang diangkut menggunakan kapal-kapal berukuran besar. Pelabuhan Patimban juga akan didukung area sarana penunjang untuk mendukung efisiensi logistik dari dan ke Pelabuhan Patimban seluas 356 Ha.

Namun dalam pembangunan Pelabuhan Patimban terdapat pro dan kontra dikalangan masyarakat sekitar Khususnya di Desa Patimban Kecamatan Pusakanegara juga umunya masyarakat di kabupaten Subang terhadap pembangunan pelabuhan, hal ini disebabkan karena mereka terkena langsung dampak dari pembangunan tersebut. Pembangunan Pelabuhan Patimban sendiri tidak dipungkiri bahwa akan memberikan dampak positif dan negatif bagi perekonomian masyarakat sekitar. Sehingga perlu diketahui terkait dampak positif dan negatif dari sisi perekonomian masyarakat sekitar di Desa Patimban Kecamatan Pusakanegara Kabupaten Subang. Hal ini yang harus disampaikan dengan komunikasi publik yang baik anatar Pemerintah Pusat, Pemerintah Daerah Kabupaten Subang dan Masyarakat yang langsung terkena dampak dari pembangunan Pelabuhan Patimban karena sangat jelas dalam hal perekonomian akan berubah drastis darai yang tadinya masyarakat di Desa Patimban Kecamatan Pusakanegara yang semula bermata pencaharian sebagai Petani dan 
Nelayan akan berubah seiring dengan berjalannya Pelabuhan Patimban. Selain itu kondisi sosialpun akan mengalami perubahan dimana yang tadinya masyarakat desa yang akan bermetamerfosis menjadi wilayah industri metropolitan yang akan mengubah kebiasaan sosial di Desa Patimban Kecamatan Pusakanegara Kabupaten Subang.

Berdasarkan uraian di atas, maka dari itu peneliti merumuskan masalahnya sebagai berikut : Bagaimana dampak pembangunan Pelabuhan Patimban terhadap kondisi sosial ekonimi masyarakat sekitar?

\section{TINJAUAN PUSTAKA}

Menurut Peraturan Menteri Perhubungan Republik Indonesia Nomor: PM 51 Tahun 2015 Tentang Penyelenggaraan Pelabuhan Laut, pelabuhan adalah tempat yang terdiri atas daratan dan/atau perairan dengan batasbatas tertentu sebagai tempat kegiatan pemerintahan dan kegiatan pengusahaan yang dipergunakan sebagai tempat kapal bersandar, naik turun penumpang, dan/atau bongkar muât barang, berupa terminal dan tempat berlabuh kapal yang dilengkapi dengan fasilitas keselamatan dan keamanan pelayaran dan kegiatan penunjang pelabuhan serta sebagai tempat perpindahan intra-dan antarmoda transportasi.

Kebijakan dari pemerintah terkait dengan pembangunan pelabuhan memberikan dampak perubahan sosial ekonomi bagi masyarakat sekitar. Dampak perubahan yang dialami oleh masyarakat sekitar adalah adanya perubahan fisik sarana dan prasarana pelabuhan yang lebih baik dari sebelumnya. Perubahan yang lain adalah dengan adanya penyerapan tenaga kerja dari usaha masyarakat dan peningkatan jumlah pendapatan bila dibandingkan dengan sebelum adanya kebijakan tersebut (Anton $\mathrm{S}$ et al., 2014).

Berdasarkan hasil penelitian yang dilakukan oleh Yusuf, et al. (2005), berbagai kelompok masyarakat berdasarkan mata pencaharian utama (nelayan, pedagang, buruh, pengolah dan petani) menyatakan bahwa pembangunan pelabuhan mempunyai dampak positif terhadap penyerapan 
tenaga kerja dan peningkatan pendapatan masyarakat sekitarnya. Sementara itu pengembangan dan pembangunan pelabuhan perikanan/ pangkalan pendaratan ikan dapat memajukan ekonomi di suatu wilayah dan sekaligus dapat meningkatkan penerimaan negara dan Pendapatan Asli Daerah. Direktorat Prasarana Perikanan Tangkap (2004) dalam Suherman dan Dault (2009).

Menurut Suherman dan Dault (2009), pembangunan pelabuhan khususnya pelabuhan perikanan nusantara (PPN) memberikan dampak positif maupun negatif bagi masyarakat. Dampak positif yaitu terjadinya peningkatan usaha dan terbukanya kesempatan kerja atau lapangan pekerjaan yang baru bagi masyarakat sekitar, dimana hal ini akan berpengaruh pada pendapatan. Sedangkan pengaruh negatif dari keberadaan pelabuhan yaitu terjadinya persaingan usaha, konflik sosial dan ketersediaan sumberdaya ikan yang semakin berkurang.

Menurut Emil Salim (1992, hlm 3) mengatakan bahwa pembangunan berkelanjutan dapat berdampak positif maupun negative. Dampak positif dari pembangunan adalah dapat meningkatkan kualitas hidup yang terdiri dari meningkatnya kualitas fisik, turunnya angka kematian, dan meningkatkan kesejahteraan. Sedangkan dampak negative dari pembangunan yaitu berkurangnya sumber daya, pencemaran lingkungan, dan redistribusi penduduk. Sedangkan menurut Soediono (1985:17) yaitu: "Pembangunan merupakan perubahan susunan dan pola masyarakat yang akan merangsang lapisan-lapisan masyarakat dan dengan adanya teknologi maka pertumbuhan ekonomi akan semakin pesat”.

\section{Teori Pembangunan}

Pembangunan adalah proses perubahan dari tradisional menju ke arah yang modernisasi. Dari masyarakat yang statis menuju masyarakat yang lebih dinamis yang mencakup kedalam 3 aspek yaitu aspek ekonomi, aspek sosial dan aspek lingkungan. Para ahli mempunyai definisi yang bermacam-macam mengenai pengertian pembangunan. Menurut Riyadi dan Deddy Supriyadi Bratakusumah, (2005) mengatakan bahwa pembangunan merupakan suatu proses 
untuk melakukan suatu perubahan bagi wilayah atau negara tersebut. Siagian (1994) mempunyai definisi mengenai pembangunan yaitu suatu usaha atau rangkaian usaha pertumbuhan dan perubahan yang berencana dan dilakukan secara sadar oleh suatu bangsa, negara dan pemerintahan, menuju modernitas dalam rangka pembinaan bangsa (nation building).

Sedangkan menurut Ginanjar Kartasasmita (1994) memberikan pengertian yang cukup sederhana mengenai pembangunan yaitu suatu proses perubahan kearah yang lebih baik melalui upaya yang dilakukan secara terencana. Menurut Deddy T.Tikson (2005) bahwa pembangunan nasional dapat juga diartikan sebagai transformasi ekonomi, sosial dan juga budaya yang dapat melalui kebijakan dan juga strategi menuju kearah yang 14 diinginkan. Transformasi dalam struktur ekonomi, misalnya dapat dilihat melalui peningkatan atau pertumbuhan produksi yang cepat dalam sektor industri dan jasa. Transformasi dalam struktur sosial, misalnya dpat dilihat melalui penindustrian kemakmuran melalui pemerataan terhadap sumber daya sosial - ekonomi. Seperti pendidikan, kesehatan, perumahan, fasilitas umum.

Maka dari itu pembangunan juga dapat dikatakan sebagai suatu upaya terkoordinasi untuk menciptakan alternative yang lebih banyak secara sah kepada setiap warga negara untuk memenuhi dan juga mencapai aspirasinya yang paling manusiawi (Nugroho dan Rochmin Dahuri, 2004). Beberapa para ahli menganjurkan bahwa pembangunan suatu daerah haruslah mencakup dalam tiga hal inti nilai (Kuncoro 1997, Todaro 1983) :

a. Ketahanan (Sustenance): kemampuan untuk memenuhi kebutuhan pokok (pangan, papan, kesehatan, dan proteksi) untuk mempertahankan hidup.

b. Harga diri (Self Esteem): pembangunan haruslah memanusiakan orang. Dan dalam arti luas pembangunan suatu daerah haruslah meningkatkan kebanggaan sebagai manusia yang berada di daerah tersebut. 
c. Freedom from servitude : kebebasan bagi setiap individu suatu negara atau daerah untuk berpikir, berkembang berperilaku dan berusaha untuk berpatisipasi dalam pembangunan.

\section{Kondisi Sosial dan Kondisi Ekonomi}

Kondisi Sosial Adalah suatu masyarakat selalu berkaitan dengan keadaan kehidupan masyarakat di suatu wilayah. Kondisi kehidupan masyarakat ini dapat dilihat dari segi ras dan etnis yang ada diwilayah itu, mata pencariannya, agama yang dianut, tingkat kesejahteraan, nilai atau norma yang dianut masyarakat, kesehatan, dan pendidikan juga termasuk dalam kondisi sosial. Kondisi sosial memang tidak dapat terlepas dari kondisi fisik suatu wilayah tersebut.

\section{Mata Pencaharian}

Mata pencarian merupakan aktifitas manusia untuk memperoleh taraf hidup yang layak dimana antara daerah satu dengan daerah lainnya yang berbeda sesuai taraf kemampuan penduduk dan keadaan demografinya (Daldjoeni, 1987 : 89).

\section{Mobilitas Penduduk}

Menurut Sumaatmadja (1981: 147 ) mobilitas penduduk adalah pergerakan penduduk dari satu tempat ketempat lain, baik untuk memenuhi kebutuhan ekonomi maupun untuk memenuhi kebutuhan sosial lainnya.

\section{METODE PENELITIAN}

Penelitian ini menggunakan pendekatan penelitian kualitatif yaitu penelitian yang dapat diartikan sebagai prosedur pemecahan masalah yang diselidiki dengan menggambarkan, melukiskan keadaan subyek atau obyek penelitian pada saat sekarang berdasarkan fakta-fakta yang tampak atau sebagaimana adanya. Teknik pengumpulan data, yaitu: observasi, 
wawancara, dan dokumentasi. Teknik keabsaan data yang digunakan dalam penelitian ini yaitu triangulasi sumber dan triangulasi metode. Teknik analisis data yang digunakan dalam penelitian ini yaitu teknik analisis data kualitatif, yaitu pengumpulan data, reduksi data, penyajian data, dan penarikan kesimpulan/verifikasi.

\section{HASIL DAN PEMBAHASAN}

Kebijakan Presiden Jokowi Widodo yang dituangkan dalam Peraturan Presiden No 47 Tahun 2016 Tentang Penetapan Pelabuhan Patimbang Di Kabupaten Subang Provinsi Jawa Barat Sebagai Proyek Strategi Nasional disambut dengan bahagia oleh berbagai kalangan baik dari Kalangan Pemerintah Pusat, Pemerintah Daerah maupun dari kalangan masyarakat bagaimana tidak pembangunan Pelabuhan Patimban diharapkan mampu membawa perubahan yang signifikan terutama dalam meningkatkan pertumbuhan ekonomi yang lebih baik lagi dari sebelum adanya Pelabuhan Patimban selain itu Pelabuhan Patimban juga diharapkan mampu mengurangi tingkat pengangguran di Kabupaten Subang dan membuka peluang kerja yang sebesar-besarnya di lingkungan masyarakat sekitar yang terkena dampak langsung pembangunan Pelabuhan Patimban. Pembangunan Pelabuhan Patimbang di Kecamatan Pusakanegara Kabupaten Subang dengan kapasitas 7,5 Juta TEUS peti kemas dan 600.000 CBU kendaraan akan dimulai pada Januari 2018 dan diharapkan terjadi soft opening pada Maret 2019 kemudian pada 20 Desember 2020 diresmikan tahap pertama oleh Presiden Republik Indonesia Jokowi Widodo. Sedangkan tahap penyelesaian secara menyuluruh ditargetkan selesai pada tahun 2027.

Nantinya Pembangunan Pelabuhan Patimban yang berada di Kabupaten Subang bisa terkoneksi dengan kawasan penting lainnya seperti Bandara Kertajati di Kabupaten Majalengka dan juga kawasan industri di Bekasi, Karawang dan Purwakarta. Harapannya adalah ketika proses pembangunan Pelabuhan Patimban ini berjalan lancar dan dapat selesai 
tepat waktu akan menghasilkan Segitiga kawasan pertumbuhan ekonomi yaitu Patimban, kemudian Bandara Kertajati dan juga kawasan industri di Bekasi, Karawang dan Purwakarta sebagai sebuah kawasan industri yang saling terkait berhubungan dan terkoneksi saling mendukung satu dengan yang lainnya. Sehingga arah ke depan dalam proses pengembangannya dapat menjadi konkret dan jelas mempunyai segmen yang saling komplementer, saling mengisi, dan saling berhubungan satu dengan yang lainnya. Langkah ini diharapkan mampu serta dapat mempercepat pertumbuhan sentra-sentra ekonomi regional serta membuat produkproduk ekspor semakin efisien dan kompetitif.

Pemerintah Pusat berharap pembangunan Pelabuhan Patimban dapat menjadi episentrum baru dalam pengembangan serta peningkatan pertumbuhan ekonomi di luar Jakarta kita ketahui bersama selama ini Jakarta masih menjadi pusat perekonomian nasional ketika Pelabuhan Patimban sudah mulai beroperasi bisa mendorong roda perekonomian baru di daerah Rebana (Cirebon, Subang dan Majalengka). Pelabuhan Patimban menjadi sangat strategis di masa yang akan datang karena ditopang oleh infrastruktur pendukung antara lain Bandara Kertajati dan akses jalan tol.

Dibalik mewah dan megahnya pembangunan Pelabuhan Patimban yang menyimpan harapan besar untuk perubahan serta pertumbuhan ekonomi regional menyimpan dampak sosial yang sangat terasa di masyarakat sekitar Pelabuhan Patimban yang secara langsung dampak tersebut dirasakan. Terutama dalam hal ini yang sangat merasakan dampak dari pembangunan ini adalah para Nelayan. Selama ini permasalahan para Nelayan di Patimban ketika melakukan dialog dengan berbagai perwakilan Nelayanan yang terkena dampak langsung adalah kurangnya modal untuk melaut yang lebih jauh lagi jaraknya selain itu permasalahan lainnya adalah kebiasaan para Nelayan yang terbiasa melaut dengan jarak dekat atau melaut di pinggir dan tidak terlalu jauh ke lepas pantai ditambah dengan alat-alat melaut yang sangat masih tradisional. Selama pembangunan Pelabuhan Patimban ini berlangsung sangat terasa sekali dirasakan oleh para nelayan setempat dengan jarak melaut yang 
tidak terlalu jauh ditambah pembangunan Pelabuhan yang menghabiskan bibir pantai sehingga mengakibat penghasilan para nelayan yang semakin berkurang.

Adapun point-point yang menjadi dampak pembangunan Pelabuhan Patimban akan dibahas secara detail pada point-point sebagai berikut :

\section{Kondisi Sosial Ekonomi}

Perubahan yang terjadi pada masyarakat di Desa Patimban Kecamatan Pusakanegara dan sekitarnya yang mengalami suatu proses pembangunan Pelabuhan Patimban pembangunan ini digadang-gadang menjadi pelabuhan terbesar setelah Pelabuhan Tanjung Priuk. Pembangunan Pelabuhan Patimban ini merupakan suatu gejala yang wajar jika dilihat dari arti pembangunan yang merupakan usaha sadar, terencana dan terus menerus yang dilakukan oleh suatu bangsa, negara dan pemerintah menuju modernitas untuk memperbaiki kualitas hidup masyarakat melalui pemanfaatan yang dimiliki. Perubahan persepsi atau pandangan pada masyarakat di Desa Patimban Kecamatan Pusakanegara Kabupaten Subang terjadi apabila terdapat perbedaan pandangan masyarakat sekitar terhadap adanya pembangunan Pelabuhan Patimban dan perubahan pandangan tersebut dapat mengarah pada arah yang positif atau negatif.

Dari hasil penelitian bahwa terjadi perubahan persepsi yang mengaraha kearah positif dan negatif. Dari persepsi masyarakat yang ada di Desa Patimban Kecamatan Pusakanegara dan sekitarnya bahwa masyarakat menilai adanya perubahan yang lebih baik dari sebelum adanya pembangunan Pelabuhan Patimban dulu yang tadinya Desa Patimban tidak terkenal dan tidak banyak diketahui oleh orang-orang sekarang dengan adanya pembangunan Pelabuhan Patimban masyarakat diseluruh Indonesia mengetahui Desa Patimban di Kecamatan Pusakanegara kabupaten Subang ditambah rutinitas penduduk yang tadinya sepi menjadi ramai dengan berbagai kegiatan pelabuhan. Selain itu menurut masyarakat di Desa Patimban dengan adanya Pelabuhan Patimban masyarakat yang 
berprofesi sebagai Nelayan yang semula berlayar dengan menggunakan alat-alat yang masih sangat tradisional akan mendapatkan bantuan yang lebih modern dalam berlayar menangkap ikan sebagai dampak dari adanya pembangunan Pelabuhan itu yang menjadi janji dari pemerintah untuk mensejahterakan para nelayan yang merasakan dampak langsung pembangunan Pelabuhan Patimban. Hal ini yang disambut dengan gembira oleh masyarakat yang berprofesi sebagai Nelayan karena selama ini dalam menagkap ikan masih menggunakan alat-alat yang tradisional.

Selain itu ada juga masyarakat yang berpandangan negatif dengan adanya pemangunan Pelabuhan Patimban dimana nantinya akan terjadi interaksi sosial dimana akan ada banyak penduduk yang datang dari luar wilayah baik yang datang sebagai pencari kerja karena nantinya akan ada banyak perusahaan yang beroperasional di Pelabuhan Patimban. Tentu hal ini lambat laun akan merubah kebiasaan masyarakat sekitar seiring dengan perkembangan Pelabuhan Patimban karena banyaknya pendatang yang datang dari berbagai daerah dengan membawa kebiasaannya masingmasing. Itu semua bagian dari realita yang tidak bisa dihindarkan dari konsekuensi adanya pembangunan yang telah diprogramkan oleh Pemerintah Pusat dengan tujuan meningkatkan ekonomi dan kesejahteraan rakyat. Pengembangan dan peningkatan Pelabuhan Patimban di Kecamatan Pusakanegara Kabupaten Subang memberikan kesempatan kerja yang seluas-luasnya bagi masyarakat sekitar yang terkena dampak pembangunan. Berdasarkan data yang diperoleh peneliti melalui kebijakan Pemerintah Daerah serta Pemerintah Pusat memberikan kesempatan kepada masyarakat untuk membuka berbagai macam usaha yang secara tidak langsung memberikan kesempatan berwirausaha bagai masyarakat sekitar yang terkena dampak pembangunan. Adanya pembebasan lahan serta ganti rugi lahan yang diberikan pemerintah kepada masyarakat telah membuka pikiran untuk mengelola uang tersebut sebagai bentuk usaha antara lain membeli lahan pertanian di tempat lain, membuka rumah makan, kios dan kontrakan ini dilakukan masyarakat agar uang ganti rugi tidak habis dan ekonomi terus berputar dibalik dampak pembangunan 
Pelabuhan Patimban. Harapannya adalah ketika semua itu berjalan dengan baik dan lancar usaha tersebut mampu menyerap tenaga kerja warga sekitar tentu ini semua harus tetap dalam pengawasan pemerintah serta pemerintah memberikan pelatihan ekonomi kepada masyarakat. Namun dalam pelaksanaanya ternyata pembangunan Pelabuhan Patimban secara tidak langsung telah mendorong terjadinya perubahan sosial ekonomi pada masyarakat sekitar, khususnya masyarakat di Desa Patimban Kecamatan Pusakanegara Kabupaten Subang. Dari segi sosial perubahan dapat dilihat dari perubahan persepsi masyarakat Desa Patimban terhadap pembangunan Pelabuhan Patimban yaitu perubahan kondisi lingkungan yang lebih ramai dibanding dulu sebelum adanya pembangunan Pelabuhan Patimban. Sedangkan dari segi ekonomi, perubahan tersebut dapat dilihat dari jumlah penyerapan tenaga kerja yang tinggi terjadi di sekitar lokasi pembangunan Pelabuhan Patimban.

\section{Mata Pencaharian}

Mata pencaharian utama masyarakat disekitaran Desa Patimban pada umumnya adalah sebagai Nelayan, baik Nelayan Tradisional mupun yang sudah mengalami modifikasi ke arah yang lebih modern kebanyakannya masih sangat tradisional, selain Nelayan ada juga yang berprofesi sebagai Petani dan buruh. Dengan adanya Pelabuhan Patimban ini secara langsung maupun tidak langsung akan berdampak kepada profesi tersebut seperti yang telah dijeleskan sebelumnya bahwa Nelayan akan terdampak langsung yaitu jarak melaut yang semakin jauh ditambah dengan peralatan yang masih sangat tradisional. Para Nelayan mengaku sangat khawatir dengan mata pencahariannya kehadiran Pelabuhan Patimban akan berdampak serius terhadap para Nelayan dan ini yang menjadi PR pemerintah adalah bagaimana kehadiran Pelabuhan Patimban tidak sampai menghilakan mata pencaharian Nelayan di Desa Patimban Kecamatan Pusakanegara Kabupaten Subang. Kondisi seperti ini langsung direspon cepat oleh pemerintah melalui Kementerian terkait dengan memberikan bantuan perahu yang lebih bagus dari perahu yang sering 
digunakan oleh Nelayan agar mata pencahariannya tidak hilang dan Nelayan masih bisa untuk melaut.

Selain itu dampak yang sama dirasakan juga oleh para Petani karena pembangunan Pelabuhan Patimban yang banyak menghabiskan lahan pertanian berdampak pada mata pencaharian para Petani, namun dalam hal ini dampak tersebut tidak terlalu dirasakan karena ada program pembebasan lahan dengan ganti rugi lahan yang terkena dampak pembangunan sehingga para Petani mendapatkan uang ganti rugi dan bisadiperuntukan lagi dengan membeli lahan pertanian di wilayah lain atau juga bisa digunakan untuk berwirausaha. Namun disisi lain adalah dampak bagi petani yang lain yang lahannya tidak terkena dan masih bisa bertani tetapi kesulitan akses perairan untuk lahan sawahnya. Memang ini bagian dari dampak pembangunan ada yang diuntungkan dan ada juga yang dirugikan. Kemudian para pemuda werga sekitar akan mendapatkan keuntungan dengan dibukanya lowongan pekerjaan sebagia dampak dari pembangunan pelabuhan yaitu dibangunnya perusahan-perusahan sebagai penopang kegiatan industri di kawasan Pelabuhan Patimban. Karena nantinya di Pelabuhan Patimban akan menjadi wilayah industri penopang wilayah industri Bekasi, Karawang dan Purwakarta dan Kabupaten Subang wilayah Utara akan jadi Kota Metropolitan baru hal ini yang harus dibarengi dengan kemampuan dan keahlian warga sekitar agar tidak menjadi penonton di wilayah sendiri.

\section{Mobilitas Penduduk}

Mobilitas penduduk merupakan bagian dari proses pembangunan Pelabuhan Patimban secara keseluruhan. Mobilitas telah menajdi penyebab dan penerima dampak dari perubahan dalam struktur ekonomi dan sosial suatu daerah tepatnya di Desa Patimban Kecamatan Pusakanegara Kabupaten Subang dengan diresmikannya pembangunan pelabuhan yang akan menjadi pusat industri selain dari kawasan Bekasi, Karawang dan Purwakarta yang nantinya mobilitas penduduk akan tinggi dimana warga masyarakat akan datang dan pergi silih berganti. Oleh karenanya akan banyak perspektif yang hadir dikalangan masyarakat ada yang menilai 
positif ada juga yang menilai negatif tergantung dari bagaimana masyarakat merasakan dampak dari pembangunan Pelabuhan Patimban. Tidak akan terjadi proses pembangunan tanpa adanya mobilitas penduduk. Tetapi juga tidak akan terjadi pengarahan penyebaran penduduk yang berarti tanpa adanya kegiatan pembangunan itu sendiri.

Pada pembangunan Pelabuhan Patimban terdapat penduduk yang terkena dampak pembangunan secara langsung dan aja juga yang tidak langsung. Penduduk yang terkena dampak secara langsung adalah penduduk yang bertempat tinggal di daerah tapak pembangunan Pelabuhan Patimban dan semua asetnya terkena pembangunan Pelabuhan Patimban sehingga harus pindah hal ini yang dirasakan oleh masyarakat yang secara langsung terkena dampaknya melalui proses ganti rugi yang diberikan oleh pemerintah sebagai dampak pembangunan pelabuhan. Uang ini yang dijadikan untuk modal mencari tempat tinggal baru ataupun bisa dipergunakan untuk memulai modal usaha demi keberlangsungan hidupnya. Kemudian penduduk yang tidak terkena langsung pembangunan Pelabuhan Patimban adalah penduduk yang bermukin di luar tapak pembangunan Pelabuhan Patimban yang mempunyai aset di daerah tempat pembangunan pelabuhan dan penduduk yang tidak mempunyai aset di daerah tempat pembangunan pelabuhan tetapi merupakan sumber penghidupannya yaitu Petani dan buruh tani. Hal ini yang amat terasa adalah petani dan selain nelayan yang merasakan akibat dampak pembangunan lahan pertanian yang berubah menjadi lahan industri nantinya.

Mobilitas penduduk yang terkena dampak pembagunan Pelabuhan Patimban memberikan arti tersendiri dalam konteks mobilitas penduduk. Mobilitas penduduk yang terkena pembangunan Pelabuhan Patimban lebih bersivat individual dan kepindahannya direncanakan secara matang dan ada niatan untuk pindah. Mobilitas penduduk yang terkena pembangunan Pelabuhan Patimban lebih bersifat kolektif perencanaannya tidak matang kepindahannya terpaksa atau tidak ada niatan pindah. Hal ini yang dirasakan oleh masyarakat sekitar yang terkena dampak langsung 
pembangunan Pelabuhan Patimban mereka ada yang merencanakan dengan matang ada juga yang mereka tidak niat untuk pindah faktor ini lebih kepada ketakutan akan mata pencaharian mereka yang nantinya akan hilang selama berpuluh-puluh tahun mereka sudah tinggal di Desa Patimban dengan bermata pencaharian mayoritas sebagai Petani sawah dan Nelayan hal ini yang dikhawatirkan nantinya jika mereka harus pindah namun disisi lain mereka tidak bisa menolak karena sudah menjadi kebijakan pemerintah untuk membangun Pelabuhan Patimban dalam rangka untuk meningkatkan pertumbuhan ekonomi dan kesejahteraan masyarakat.

Dari temuan di lapangan yang dianalisis oleh penulis serta bersumber dari keterangan warga masyarakat bahwa mobilitas penduduk yang disebabkan oleh adanya pembangunan Pelabuhan Patimban meliputi tiga pola yaitu diatur pemerintah, keinginan sendiri dan tergantung orang lain. Diatur oleh pemerintah nerupakan bagian dari program dampak pembangunan karena pembangunan Pelabuhan Patimban yang banyak menghabiskan lahan penduduk serta persawahan sehingga pemerintah mengatur perpindahan penduduk dengan program ganti rugi lahan dari ganti rugi lahan itu masyarakat diberikan pengetahuan untuk mengelola uang dengan memberi penjelasan dalam perpindahan penduduk yang diatur oleh pemerintah sehingga lahan yang tergusur tergantikan dengan lahan ditempat lain melalui program ganti rugi lahan ini. Keinginan sendiri merupakan suatu kesadaran masyarakat akan dampak yang dirasakan dari pembangunan Pelabuhan Patimban mereka sadar lahannya yang akan menjadi bagian dari penggusuran berinisiatif dengan melakukan perpindahan tentunya dengan mengedepankan aturan yang telah dibuat oleh Pemerintah perihal penggusuran ini mereka sadar akan kehilangan tempat tinggalnya sehingga mencarai tempat tinggal baru melalu program ganti rigi lahan yang terkena dampak. Kemudian yang ketiga adalah tergantung orang lain ini biasanya yang paling berbahaya yang akan menimbulkan konflik baru dimana tidak semua orang suka dengan adanya pembangunan Pelabuhan Patimban ini ada yang mendukung ada juga yang 
tidak dikhawatirkan mereka mengikuti orang yang tidak suka sehingga mereka ikut-ikut untuk menolak digusur dan dipindahkan sehingga menimbulkan konflik dan terganggunya pembangunan Pelabuhan Patimban.

\section{KESIMPULAN}

Pembahasan yang sudah disajikan di atas dapat ditarik kesimpulan bahwa dampak pembangunan Pelabuhan Patimban di Kecamatan Pusakanegara Kabupaten Subang terhadap kondisi sosial ekonomi masyarakat sekitar memberikan dampak pada kehidupan masyarakat, yaitu kondisi sosial ekonomi, mata pencaharian dan mobilitas penduduk.

Kondisi sosial ekonomi dimana terjadi perubahan interaksi sosial dimana masyarakat yang tadinya rutinitas terbatas dan sepi kini menjadi lebih ramai seiring dengan beroperasinya Pelabuhan Patimban, ditambah dengan roda perekonomian yang berubah dari yang tadinya sektor pertanian dan melaut berubah menjadi sektor industri.

Mata pencaharian yang berubah drastis yaitu dari sektor pertanian karena lahan-lahan sawah yang berkurang dan berubah menjadi pusat industri dan sektor laut yaitu Nelayan yang dirasakan dampaknya begitu terasa dengan jangkauan melaut yang semakin jauh dari bibir pantai.

Mobilitas penduduk terjadinya perpindahan penduduk baik yang diatur oleh pemerintah, kemauan sendiri dan tergantung orang lain. 


\section{DAFTAR PUSTAKA}

Al Muftiani, RAHMA. 2019. KERJASAMA INDONESIA-JAPAN INTERNATIONAL COOPERATION AGENCY (JICA) DALAM IMPLEMENTASI PROYEK PATIMBAN PORT DEVELOPMENT PROJECT SEBAGAI PELABUHAN INTERNASIONAL

Anton S. M., Mardiyono \& Prasetya, W. Y. (2014). Evaluasi Dampak Kebijakan Pembangunan Pelabuhan Perikanan Pantai (PPP) Tamperan Terhadap Perubahan Sosial Ekonomi Masyarakat Pesisir Sekitar (Studi Kasus pada PPP Tamperan Kab. Pacitan). Jurnal Administrasi Publik (JAP), 2(11), 1010-1015

Aqwan, Aziz Irsyadul. 2016. Dampak Pembangunan Pelabuhan Patimban Terhadap Kondisi Sosial Ekonomi Masyarakat Sekitar.

Daldjoeni, N. 1987. Geografi Kota Dan Desa. Bandung : Alumni

Deddy T. Tikson. 2005. Indikator-indikator Pembangunan Ekonomi. http://ecozon.html. Diakses pada: Jumat, 22 Januari 2021

Emil Salim, Lingkungan Hidup dan Pembangunan, Jakarta, Mutiara Sumber Widya, 1989.

Ghosh, Buddhadeb and Prabir De (2005). "Investigating The Linkage Between Infrastructure and Regional Development in India". Journal of Asian Economics Elsevier. G

Ginanjar, Kartasasmita, 1994 : Pembangunan Untuk Rakyat, Memandukan Pertumbuhan Dan Pemerataan, PT. Pustaka CIDES INDO, Jakarta.

Keusuma, Cut Nanda. 2014. Pengaruh Pembangunan Infrastruktur Dasar Terhadap Pertumbuhan Ekonomi Di Indonesia.

Kuncoro, Mudrajad. 2010. Dasar - dasar Ekonomika Pembangunan. Yogyakarta : UPP STIM YKPN.

Lee, Everett S, 1987, Suatu Teori Migrasi, Yogyakarta, Pusat Penelitian Kependudukan, Universitas Gadjah Mada

Nugroho, I. Dan Rochimin Dahuri. 2004. Pembangunan Wilayah : Perspektif Ekonomi, Sosial dan Lingkungan. Jakarta : LP3ES

Priyanti, Novalia Fris. 2017. ANALISIS KONDISI EKONOMI DAN SOSIAL SEBELUM DAN SESUDAH ADANYA PEMBANGUNAN JALAN TOL GEMPOL-PANDAAN.

Riyadi dan Deddy Supriyadi Bratakusumah. 2005. Perencanaan Pembangunan Daerah. Jakarta : PT Gramedia Pustaka Utama.

Siagian, Sondang P, 1994, Administrasi Pembangunan, Gedung Agung, Jakarta.

Soediono. 1985. Ekonomi Makro: Pengantar Analisis Pendapatan Nasional. Yogyakarta: Liberty. 
Somadi. 2019. Cost-Benefit Analysis Pembangunan Pelabuhan Patimban Terhadap Masyarakat Pesisir Di Kabupaten Subang.

Suherman, A. dan Dault, A. (2019). Dampak Sosial Ekonomi Pembangunan dan Pengembangan Pelabuhan Perikanan Nusantara (PPN) Pengambengan Jembrana Bali. Jurnal Saintek Perikanan, 4(2), 2432.

Sumaatmadja. 1981. Studi Geografi Suatu Pendekatan dan Analisa Keruangan. Bandung : Alumni

Suwartapraja, Opan S. DAMPAK PEMBANGUNAN TERHADAP KEPENDUDUKAN (Studi Tentang Mobilitas Eksternal Pada Pembangunan Bendungan di Jawa Barat). Universita Padjajaran Bandung.

Todaro, Michael dan Smith. 2006. Pembangunan Ekonomi di Dunia Ketiga. Jakarta: Erlangga. Penterjemah: Drs. Haris Munandar, MA; Puji A.L, SE.

Triatmodjo, Bambang; 1996, Pelabuhan, Beta Offset, Yogyakarta.

Waluyo, Dwi Eko "Karakteristik Sosial Ekonomi dan Demografi Anak Jalanan", diunduh 22 Januari 2021 dari http://id.wikipedia.org/wiki/Anak_jalanan.

Yusuf, H., Moedikdjo, K., Saeni, M. S., \& Nasution, L. I. (2015). Dampak Pembangunan Pelabuhan Perikanan Terhadap Penyerapan Tenaga Kerja Dan Pendapatan Masyarakat (Studi Kasus di Pelabuhan Perikanan Lempasing, Bandar Lampung). Buletin Ekonomi Perikanan, 6(1), 57-64.

Peraturan Menteri Perhubungan Republik Indonesia Nomor: PM 51 Tahun 2015 Tentang Penyelenggaraan Pelabuhan Laut.

Peraturan Presiden No 47 Tahun 2016 Tentang Penetapan Pelabuhan Patimbang Di Kabupaten Subang Provinsi Jawa Barat Sebagai Proyek Strategi Nasional 